Температурная зависимость термовлектродвижущей силь серово олова ...

Эти результаты находятся в согласии с теорией Тауца [1]. Аналогичные результаты получены в [10], где измерения производились на германии с примесью алюминия.

Отсюда можно заключить, что свойства серого олова в отношении температурной зависимости ТЭДС подобны свойствам германия.

\title{
РЕЗУЛЬТАТЫ
}

1. Измерена электропроводимость чистого серого олова и олова с примесью кадмия. Не обнаружено пропорциональности между количеством содержкания примеси и проводимостью. Энергия активации растет с ростом содержания примесей.

2. ТӘДС в образцах с преимущественно электронной проводимостью отрицательна во всем температурном диапазоне.

3. В образцах с большим количеством примесей ТЭДС при низких температурах положительна, убывает с повышением температуры до нуля и становится отрицательной.

Поступило 20. 1. 1956.

\section{THE TEMPERATURE DEPENDENCE OF THE THERMAL EMF OF GREY TIN ALLOYED WITH CADMIUM}

(Abstract of preceding paper)

Petro R. Kamadžrev

Mathematico-Physical Faculty, Sofia

\begin{abstract}
The thermal emf and electric conductivity as a function of the temperature in the range $-183^{\circ}$ to about $10^{\circ} \mathrm{C}$ was measured on samples of grey tin alloyed with cadmium in concentrations given in the table on p. 443. The specimens were prepared by alloying spectrally pure tin, which was then cooled in a closed container for a longer period at $-40^{\circ}$ to $-50^{\circ} \mathrm{C}$ so that during the charge there occurred compression of the individual grains. The results of measuring the electric conductivity are given in Fig. 1, those of the thermal emf in Fig. 2. By analysing the results it was found that the activation energy increases with increasing concentration of cadmium and that the cadmium behaves as a $p$-type impurity since specimens sufficiently alloyed with cadmium have a positive sign at lower temperatures, which becomes negative on entering the region of intrinsic conductivity when the influence of the electrons predominates.
\end{abstract}

Received 20. 1. 1956.

\section{Jumepamypa - References}

[1] Tauc J.: Czechosl. Journ. Phys. 3 (1953), 282.

[2] Конторова-Т. А.: ЗКТФ 24 (1954), 1687.

[3] Блум А. И., Юрюнова Н. А.: ДАН СССР 25 (1950), 367.

[4] Kamadžiev P. R.: Cs. čas. fys. 4 (1954), 424 .

Kamadžiev P. R.: Чехосл. Физ. журн. 5 (1955), 1 .

[5] Камаджиев П. Р.: Год. Соф. У-т 18, кн. І, ч. I (1953), 217.

[6] Busch G., Wieland I.: Helvetica Physica Acta, fase. 7 et 8 (1953), 697.

[7] Šmirous K.: Чехосл. Физ. журн. 3 (1953), 175.

[8] Ewald A. W. and Kohnke E. E.: Phys. Rev. 97 (1955), 607.

[9] Kendall J. T.: Phil. Mag. 45 (1954), 141.

[10] Middleton A. E., Scanlon W. W.: Phys. Rev. 92 (1953), 219. 